\title{
Room-temperature NIR phosphorescence of new iridium (III) complexes with ligands derived from benzoquinoxaline ${ }^{1}$
}

\author{
Hsing-Yi Chen, Cheng-Han Yang, Yun Chi, Yi-Ming Cheng, Yu-Shan Yeh, \\ Pi-Tai Chou, Hsi-Ying Hsieh, Chao-Shiuan Liu, Shie-Ming Peng, and \\ Gene-Hsiang Lee
}

\begin{abstract}
A new series of new iridium (III) complexes (1-5) bearing ligands derived from benzoquinoxaline were designed and synthesized. X-ray structural analyses of $\mathbf{1}$ reveal a distorted octahedral geometry around the Ir atom in which the pyrazolate chelate is located opposite to the cis-oriented carbon donor atoms of benzoquinoxaline, while the benzoquinoxaline ligands adopt an eclipse configuration and their coordinated nitrogen atoms and carbon adopt transand cis-orientation, respectively. Complexes 1-5 exhibit moderate NIR phosphorescence with peak maxima located at around $910-930 \mathrm{~nm}$. As supported by the TDDFT approach, the transition mainly involves benzoquinoxaline ${ }^{3} \pi-\pi^{*}$ intraligand charge transfer (ILCT) and metal (Ir) to benzoquinoxaline charge transfer (MLCT) of which the spectroscopy and dynamics of relaxation have been thoroughly investigated. The relatively weak NIR emission can be tentatively rationalized by the low energy gap of which the radiationless deactivation may be governed by nearly temperature-independent, weak-bonding motions in combination with a minor channel incorporating small torsional motions associated with phenyl ring in the benzoquinoxaline sites.
\end{abstract}

Key words: phosphorescence, NIR, iridium, benzoquinoxaline, isoquinoline, bipyridine, pyrazolate, acetylacetonate.

Résumé : On a préparé une nouvelle série de complexes de l'iridium(III) (1-5) portant des ligands dérivés de la benzoquinoxaline. L'analyse des données structurales du composé $\mathbf{1}$, obtenues par diffraction des rayons X, révèle la présence d'une géométrie octaédrique déformée autour de l'atome d'iridium dans laquelle le chélate pyrazolate se trouve à l'opposé des atomes de carbone donneurs de la benzoquinoxaline orientés en cis, alors que les ligands benzoquinoxaline adoptent une conformation éclipsée et que leurs atomes d'azote coordonnés adoptent respectivement des orientations cis et trans. Les complexes 1-5 présentent de la phosphorescence modérée dans le proche infrarouge (PIR) avec un pic maximal situé autour de 910 à $930 \mathrm{~nm}$. Tel que le prédit l'approche TDDFT, la transition implique principalement un transfert de charge interligand (TCIL) ${ }^{3} \pi-\pi^{*}$ de la benzoquinoxaline et un transfert de charge du métal (iridium) à la benzoquinoxaline (TCML) dont on a étudié à fond la spectroscopie et la dynamique de relaxation. L'émission relativement faible dans le proche infrarouge pourrait être rationalisée en fonction d'une discontinuité de faible énergie de laquelle la désactivation sans rayonnement pourrait être orientée par des mouvements de faible liaison, pratiquement indépendants de la température, en combinaison avec une voie mineure qui incorporerait de faibles mouvements de torsion du noyau phényle dans les sites benzoquinoxalines.

Mots clés : phosphorescence, PIR, iridium, benzoquinoxaline, isoquinoléine, bipyridine, pyrazolate, acétylacétonate.

[Traduit par la Rédaction]

Received 30 June 2005. Published on the NRC Research Press Web site at http://canjchem.nrc.ca on 21 March 2006.

This paper is dedicated to Professor Arthur J. Carty; he has been our mentor, collaborator, and friend for the past 15 years.

H.-Y. Chen, C.-H. Yang, and Y. Chi. ${ }^{2}$ Department of Chemistry, National Tsing Hua University, Hsinchu 300, Taiwan. Y.-M. Cheng, Y.-S. Yeh, P.-T. Chou, ${ }^{3}$ S.-M. Peng, and G.-H. Lee. Department of Chemistry and Instrumentation Center, National Taiwan University, Taipei 106, Taiwan.

H.-Y. Hsieh. ${ }^{4}$ Department of Food Nutrition, Chung Hwa College of Medical Technology, Tainan 717, Taiwan.

C.-S. Liu. Department of Chemistry, SooChow University, Taipei 111, Taiwan.

${ }^{1}$ This article is part of a Special Issue dedicated to Professor Arthur Carty.

${ }^{2}$ Corresponding author (e-mail: ychi@mx.nthu.edu.tw).

${ }^{3}$ Corresponding author (e-mail: chop@ntu.edu.tw).

${ }^{4}$ Corresponding author (e-mail: simn1628@ms26.hinet.net). 


\section{Introduction}

Transition metal complexes, which exhibit strong emission in fluid solution at room temperature, have been extensively investigated owing to their fundamental interest and key roles in the design of novel systems for solar energy conversion (1), telecommunication and other optical technologies (2), as well as fabrication of high efficiency phosphorescent organic light emitting devices (OLEDs) (3). So far, most of the reported luminescent metal complexes emit in the visible region, while studies of emission properties in the NIR region are relatively rare. One reason lies in that decreasing the energy gap toward NIR may trigger a much faster radiationless decay channel because of the interaction between ground and emitting states, i.e., the so-called energy gap law, giving rise to poor quantum efficiencies (4).

The first class of complexes showing notable NIR luminescence should be credited to the lanthanide complexes incorporating the $\mathrm{Nd}(\mathrm{III}), \mathrm{Yb}(\mathrm{III})$, and $\mathrm{Er}(\mathrm{III})$ ions (5). Sharp emission signals for lanthanide complexes are expected simply because the $4 \mathrm{f}$ orbitals in the lanthanide elements are buried deep within the atom and would not be seriously coupled with the ligand vibration motions, as opposed to the broad $\mathrm{d}-\mathrm{d}$ transitions of the transition metals. As a second class, the Pd porphyrinate types of complexes are documented as exhibiting moderate NIR phosphorescence in the fluid state at room temperature, a property which is desirable for application as oxygen sensors for biomedical applications in vivo (6). The third class consists of the polypyridyl complexes involving the $\operatorname{Re}(\mathrm{I}), \mathrm{Ru}(\mathrm{II})$, and $\mathrm{Os}(\mathrm{II})$ metal ions with the $\mathrm{d}^{6}$ electronic configuration (7). Their systematic synthesis has remained as the outstanding issue in view of applications. These complexes typically absorb appreciably in the high energy region of the spectra, accompanied by the MLCT absorptions at lower energy, as well as a certain degree of contribution from direct ${ }^{3}$ MLCT absorption, a result of the heavy atom enhanced spin-orbit coupling. Accordingly, NIR phosphorescent emissions are achievable for systems with extended electronic delocalization between the metal and ligands in both ground and excited states, making them important as light harvesting sensitizers for solar cell applications.

As an extension of our contribution to the third-row metal phosphorescent materials, we have embarked on the development of Ir(III)-based metal complexes showing detectable luminescence in the NIR spectral region. The key designing feature is to utilize a diphenyl substituted benzoquinoxaline ligand that allows formation of a highly extended $\pi$ conjugation. The choice of Ir as the central atom renders the advantages of linking the benzoquinoxaline ligand through facile orthometalation, affording a desirable metal-chelate bonding interaction and a presumably rigid molecular skeleton. Along this line, the emission gaps are expected to shift significantly toward the lower energy, i.e., the NIR region, without drastic reduction to the corresponding emission efficiency.

\section{Experimental section}

\section{General experiments}

The pyrazole ligands, 3-trifluoromethyl-5-(2-pyridyl)pyrazole (fppz)H and 1-(5-tert-butyl-2H-pyrazol-3-yl)isoquino- line (bpiq)H, were prepared according to the literature methods (8). Commercially available chemicals were used without further purification. All reactions were monitored by TLC with Merck silica gel plates $(0.20 \mathrm{~mm}$ with fluorescent indicator $\left.\mathrm{UV}_{254}\right)$. Compounds were visualized with 254 or $365 \mathrm{~nm}$ UV irradiation. Column chromatography was carried out using silica gel purchased from Merck (230400 mesh). Mass spectra were obtained on a JEOL SX-102A instrument operating in electron impact (EI) or fast atom bombardment (FAB) mode. ${ }^{1} \mathrm{H}$ and ${ }^{13} \mathrm{C}$ NMR spectra were recorded on a Varian INOVA-500 instrument; chemical shifts are quoted with respect to the internal standard tetramethylsilane for ${ }^{1} \mathrm{H}$ and ${ }^{13} \mathrm{C}$ NMR data. Elemental analysis was carried out with a Heraeus $\mathrm{CHN}-\mathrm{O}$ rapid elementary analyzer.

\section{Cyclic voltammetry (CV)}

CV measurements were performed using a BAS $100 \mathrm{~B} / \mathrm{W}$ electrochemical analyzer. The oxidation and reduction measurements were recorded, respectively, in anhydr. $\mathrm{CH}_{2} \mathrm{Cl}_{2}$ and anhydr. THF containing $0.1 \mathrm{~mol}^{-} \mathrm{L} \mathrm{TBAPF}$ as the supporting electrolyte, at a scan rate of $100 \mathrm{mV} \mathrm{s}^{-1}$. The potentials were measured against a $\mathrm{Ag} / \mathrm{Ag}^{+}\left(0.01 \mathrm{~mol} / \mathrm{L} \mathrm{AgNO}_{3}\right)$ reference electrode with ferrocene as the internal standard.

\section{Preparation of 2,3-diphenyl benzo[g]quinoxaline}

An anhydrous ethanol solution $(30 \mathrm{~mL})$ of 2,3-naphthalenediamine $\left(\begin{array}{llll}1.0 & \mathrm{~g} & 6.33 \mathrm{mmol}\end{array}\right)$ and benzil $(1.34 \mathrm{~g}$, $6.33 \mathrm{mmol}$ ) was heated to reflux for $5 \mathrm{~h}$. Then the solution was gradually cooled to room temperature. The solid deposited from solution was then filtered, washed with a few drops of ethanol, and dried in vacuum overnight to afford $1.8 \mathrm{~g}$ of yellow-green 2,3-diphenyl benzo[ $g$ ]quinoxaline $(5.42 \mathrm{mmol}, 86 \%)$, denoted as (dpbq)H. The yellow-colored derivative 2,3-di- $p$-tolyl benzo[ $g$ ]quinoxaline, (dtbq)H, was obtained from $4,4^{\prime}$-dimethylbenzil in a similar fashion.

\section{Spectral data for (dpbq)H}

${ }^{1} \mathrm{H}$ NMR (400 MHz, $\mathrm{CDCl}_{3}, 298 \mathrm{~K}$ ) $\delta: 8.72$ (s, 2H), 8.07 $\left(\mathrm{dd}, 2 \mathrm{H}, J_{\mathrm{HH}}=6.4,2.8 \mathrm{~Hz}\right), 7.56\left(\mathrm{~d}, 4 \mathrm{H}, J_{\mathrm{HH}}=7.2 \mathrm{~Hz}\right), 7.52$ $\left(\mathrm{dd}, 2 \mathrm{H}, J_{\mathrm{HH}}=6.4,2.8 \mathrm{~Hz}\right), 7.38-7.32(\mathrm{~m}, 6 \mathrm{H}) . \mathrm{MS}(\mathrm{EI})$ $m / z: 332\left[\mathrm{M}^{+}\right]$. Anal. calcd. for $\mathrm{C}_{24} \mathrm{H}_{16} \mathrm{~N}_{2}: \mathrm{N} 8.43, \mathrm{C} 86.72$, $\mathrm{H}$ 4.85; found: $\mathrm{N} 8.48, \mathrm{C} 86.63$, H 5.05.

\section{Spectral data for (dtbq)H}

${ }^{1} \mathrm{H}$ NMR (400 MHz, $\left.\mathrm{CDCl}_{3}, 298 \mathrm{~K}\right) \delta: 8.69$ (s, 2H), 8.09$8.06(\mathrm{~m}, 2 \mathrm{H}), 7.54-7.51(\mathrm{~m}, 2 \mathrm{H}), 7.46\left(\mathrm{~d}, 4 \mathrm{H}, J_{\mathrm{HH}}=10 \mathrm{~Hz}\right)$, $7.15\left(\mathrm{~d}, 4 \mathrm{H}, J_{\mathrm{HH}}=10 \mathrm{~Hz}\right), 2.37(\mathrm{~s}, 6 \mathrm{H}) . \mathrm{MS}(\mathrm{EI}) \mathrm{m} / \mathrm{z}: 360$ $\left[\mathrm{M}^{+}\right]$. Anal. calcd. for $\mathrm{C}_{26} \mathrm{H}_{20} \mathrm{~N}_{2}: \mathrm{N} 7.77, \mathrm{C} 86.64, \mathrm{H}$ 5.59; found: N 7.41, C 86.65, H 5.26.

\section{Preparation of $\left[(\mathrm{dpbq})_{2} \mathrm{IrCl}\right]_{2}$}

The chloride-bridged complex $\left[(\mathrm{dpbq})_{2} \mathrm{IrCl}\right]_{2}$ was synthesized according to the method reported by Nonoyama (9), involving treatment of $\mathrm{IrCl}_{3} \cdot 3 \mathrm{H}_{2} \mathrm{O}(1.0 \mathrm{~g}, 2.84 \mathrm{mmol})$ with (dpbq)H (2.83 g, $8.5 \mathrm{mmol})$ in 2-methoxyethanol $(30 \mathrm{~mL})$ for $24 \mathrm{~h}$. Then the solution was treated with water $(30 \mathrm{~mL})$ to induce precipitation of a dark brown solid. The solid was then filtered, washed with methanol, and dried under vacuum (1.8 g, $1.22 \mathrm{mmol}, 71 \%$ ). 


\section{Preparation of $\left[(\mathrm{dtbq})_{2} \mathrm{IrCl}\right]_{2}$}

On the basis of a procedure similar to that described for $\left[(\mathrm{dpbq})_{2} \mathrm{IrCl}\right]_{2}$, the $p$-tolyl-substituted complex $\left[(\mathrm{dtbq})_{2} \mathrm{IrCl}\right]_{2}$ was synthesized in $\sim 75 \%$ yield.

\section{Preparation of $\left[(\mathrm{dpbq})_{2} \operatorname{Ir}(\mathrm{fppz})\right](\mathbf{1})$}

A mixture of $\left[(\mathrm{dpbq})_{2} \mathrm{IrCl}\right]_{2}(300 \mathrm{mg}, 0.168 \mathrm{mmol}), 3-$ trifluoromethyl-5-(2-pyridyl)pyrazole (fppzH, $80 \mathrm{mg}$, $0.38 \mathrm{mmol}$ ), and $\mathrm{Na}_{2} \mathrm{CO}_{3}(100 \mathrm{mg}, 0.94 \mathrm{mmol})$ in 2methoxyethanol $(20 \mathrm{~mL})$ was heated to reflux for $4 \mathrm{~h}$. An excess of deionized water was added after cooling the solution to room temperature (RT). The precipitate was collected by filtration and washed with methanol $(10 \mathrm{~mL})$, followed by diethyl ether $(10 \mathrm{~mL})$. Black crystals of $\left[(\mathrm{dpbq})_{2} \mathrm{Ir}(\mathrm{fppz})\right]$ (1) were obtained from a mixture of $\mathrm{CH}_{2} \mathrm{Cl}_{2}$ and methanol at RT (210 mg, $0.19 \mathrm{mmol}, 58 \%$ ).

\section{Spectral data for 1}

${ }^{1} \mathrm{H}$ NMR (400 MHz, $\left.\mathrm{CDCl}_{3}, 298 \mathrm{~K}\right) \delta: 8.77$ (s, 1H), 8.64 $\left(\mathrm{d}, 1 \mathrm{H}, J_{\mathrm{HH}}=5.6 \mathrm{~Hz}\right), 8.54(\mathrm{~s}, 1 \mathrm{H}), 8.49(\mathrm{~s}, 1 \mathrm{H}), 8.05(\mathrm{~s}$, $1 \mathrm{H}), 7.94-7.88(\mathrm{~m}, 4 \mathrm{H}), 7.75\left(\mathrm{~d}, 1 \mathrm{H}, J_{\mathrm{HH}}=8.0 \mathrm{~Hz}\right), 7.72-$ $7.61(\mathrm{~m}, 5 \mathrm{H}), 7.61-7.55(\mathrm{~m}, 3 \mathrm{H}), 7.45-7.38(\mathrm{~m}, 4 \mathrm{H}), 7.35(\mathrm{t}$, $\left.1 \mathrm{H}, J_{\mathrm{HH}}=6.0 \mathrm{~Hz}\right), 7.27-7.32(\mathrm{~m}, 2 \mathrm{H}), 7.25-7.20(\mathrm{~m}, 3 \mathrm{H})$, $6.78\left(\mathrm{~d}, 1 \mathrm{H}, J_{\mathrm{HH}}=7.6 \mathrm{~Hz}\right), 6.72\left(\mathrm{t}, 1 \mathrm{H}, J_{\mathrm{HH}}=8.0 \mathrm{~Hz}\right), 6.65$ $\left(\mathrm{t}, 1 \mathrm{H}, J_{\mathrm{HH}}=7.6 \mathrm{~Hz}\right), 6.60\left(\mathrm{t}, 1 \mathrm{H}, J_{\mathrm{HH}}=7.2 \mathrm{~Hz}\right), 6.50-6.47$ $(\mathrm{m}, 2 \mathrm{H}), 6.36\left(\mathrm{~d}, 1 \mathrm{H}, J_{\mathrm{HH}}=7.2 \mathrm{~Hz}\right)$. MS (FAB, $\left.{ }^{193} \mathrm{Ir}\right) \mathrm{m} / \mathrm{z}$ : $1067\left[\mathrm{M}^{+}\right]$. Anal. calcd. for $\mathrm{C}_{57} \mathrm{H}_{35} \mathrm{~F}_{3} \mathrm{IrN}_{7}$ : N 9.19, C 64.15, H 3.31; found: N 9.09, C 64.21, H 3.62.

\section{Preparation of $\left[(\mathbf{d p b q})_{2} \operatorname{Ir}(\mathrm{bpiq})\right]$ (2)}

Procedures identical to that of $\mathbf{1}$ were followed, using $200 \mathrm{mg}$ of $\left[(\mathrm{dpbq})_{2} \mathrm{IrCl}\right]_{2}(0.112 \mathrm{mmol}), 71 \mathrm{mg}$ of (bpiq) $\mathrm{H}$ $(0.28 \mathrm{mmol})$, and $60 \mathrm{mg}$ of $\mathrm{Na}_{2} \mathrm{CO}_{3}(0.57 \mathrm{mmol})$ in $20 \mathrm{~mL}$ of 2-methoxyethanol. Black crystals of $\left[(\mathrm{dpbq})_{2} \operatorname{Ir}(\mathrm{bpiq})\right](\mathbf{2})$ were obtained from a mixture of $\mathrm{CH}_{2} \mathrm{Cl}_{2}$ and hexane at RT (74 mg, $0.085 \mathrm{mmol}, 33 \%$ ).

\section{Spectral data for 2}

${ }^{1} \mathrm{H}$ NMR $\left(400 \mathrm{MHz}, \mathrm{CDCl}_{3}, 298 \mathrm{~K}\right) \delta: 9.00(\mathrm{~s}, 1 \mathrm{H}), 8.50$ $8.43(\mathrm{~m}, 5 \mathrm{H}), 8.30(\mathrm{~s}, 1 \mathrm{H}), 7.97(\mathrm{~b}, 2 \mathrm{H}), 7.87\left(\mathrm{~d}, 2 \mathrm{H}, J_{\mathrm{HH}}=\right.$ $8.0 \mathrm{~Hz}), 7.82\left(\mathrm{~d}, 1 \mathrm{H}, J_{\mathrm{HH}}=8.0 \mathrm{~Hz}\right), 7.72\left(\mathrm{~d}, 1 \mathrm{H}, J_{\mathrm{HH}}=\right.$ $8.0 \mathrm{~Hz}), 7.69-7.58(\mathrm{~m}, 7 \mathrm{H}), 7.52\left(\mathrm{t}, 1 \mathrm{H}, J_{\mathrm{HH}}=7.2 \mathrm{~Hz}\right)$, 7.44-7.28 (m, 4H), 7.26-7.18 (m, 5H), 6.74-6.66 (m, 2H), $6.64-6.53(\mathrm{~m}, 3 \mathrm{H}), 6.45\left(\mathrm{t}, 1 \mathrm{H}, J_{\mathrm{HH}}=7.6 \mathrm{~Hz}\right), 6.31(\mathrm{~d}, 1 \mathrm{H}$, $\left.J_{\mathrm{HH}}=8.0 \mathrm{~Hz}\right), 1.37(\mathrm{~s}, 9 \mathrm{H}) . \mathrm{MS}\left(\mathrm{FAB},{ }^{193} \mathrm{Ir}\right) \mathrm{m} / \mathrm{z}: 1105$ [M+]. Anal. calcd. for $\mathrm{C}_{64} \mathrm{H}_{46} \mathrm{~F}_{3} \mathrm{IrN}_{7}: \mathrm{N}$ 8.87, C 69.54, $\mathrm{H}$ 4.19; found: N 8.79, C 69.48, H 4.56.

\section{Preparation of $\left[(\mathbf{d p b q})_{2} \operatorname{Ir}(\mathrm{bpy})\right](3)$}

A mixture of $\left[(\mathrm{dpbq})_{2} \mathrm{IrCl}\right]_{2}(200 \mathrm{mg}, 0.11 \mathrm{mmol}), 2,2^{\prime}-$ bipyridine (bpy, $45 \mathrm{mg}, 0.29 \mathrm{mmol}$ ), and $\mathrm{AgBF}_{4}(100 \mathrm{mg}$, $0.51 \mathrm{mmol})$ in $\mathrm{CH}_{2} \mathrm{Cl}_{2}(25 \mathrm{~mL})$ was stirred at $\mathrm{RT}$ for $3 \mathrm{~h}$. The solution was filtered and the filtrate was evaporated to give the crude product. Black crystals of $\left[(\mathrm{dpbq})_{2} \operatorname{Ir}(\mathrm{bpy})\right]\left[\mathrm{BF}_{4}\right]$ (3) were obtained from a mixture of $\mathrm{CH}_{2} \mathrm{Cl}_{2}$ and hexane at RT (110 mg, $0.09 \mathrm{mmol}, 41 \%)$.

\section{Spectral data for 3}

${ }^{1} \mathrm{H}$ NMR $\left(400 \mathrm{MHz}, \mathrm{CDCl}_{3}, 298 \mathrm{~K}\right) \delta: 8.71\left(\mathrm{~d}, 2 \mathrm{H}, J_{\mathrm{HH}}=\right.$ $4.8 \mathrm{~Hz}), 8.60(\mathrm{~s}, 2 \mathrm{H}), 8.55\left(\mathrm{~d}, 2 \mathrm{H}, J_{\mathrm{HH}}=8.8 \mathrm{~Hz}\right), 8.20(\mathrm{t}$, $\left.2 \mathrm{H}, J_{\mathrm{HH}}=7.6 \mathrm{~Hz}\right), 7.96\left(\mathrm{~d}, 2 \mathrm{H}, J_{\mathrm{HH}}=8.0 \mathrm{~Hz}\right), 7.86-7.80$ $(\mathrm{m}, 8 \mathrm{H}), 7.68-7.64(\mathrm{~m}, 8 \mathrm{H}), 7.49\left(\mathrm{t}, 2 \mathrm{H}, J_{\mathrm{HH}}=3.6 \mathrm{~Hz}\right), 7.40$ $\left(\mathrm{t}, 2 \mathrm{H}, J_{\mathrm{HH}}=7.6 \mathrm{~Hz}\right), 7.03\left(\mathrm{~d}, 2 \mathrm{H}, J_{\mathrm{HH}}=8.0 \mathrm{~Hz}\right), 6.75(\mathrm{t}$, $\left.2 \mathrm{H}, J_{\mathrm{HH}}=7.6 \mathrm{~Hz}\right), 6.63\left(\mathrm{t}, 2 \mathrm{H}, J_{\mathrm{HH}}=7.2 \mathrm{~Hz}\right), 6.54(\mathrm{~d}, 2 \mathrm{H}$, $\left.J_{\mathrm{HH}}=7.6 \mathrm{~Hz}\right) . \mathrm{MS}\left(\mathrm{FAB},{ }^{193} \mathrm{Ir}\right) \mathrm{m} / \mathrm{z}: 1011\left[\mathrm{M}^{+}\right]$. Anal. calcd. for $\mathrm{C}_{58} \mathrm{H}_{38} \mathrm{~F}_{4} \mathrm{IrN}_{6}$ : N 7.65, C 63.45, H 3.49; found: N 7.71, C 63.25, H 3.57.

\section{Preparation of $\left[(\mathrm{dtbq})_{2} \operatorname{Ir}(\mathbf{f p p z})\right](4)$}

Procedures identical with that of $\mathbf{1}$ were followed, using $200 \mathrm{mg}$ of $\left[(\mathrm{dtbq})_{2} \mathrm{IrCl}\right]_{2}(0.106 \mathrm{mmol}), 113 \mathrm{mg}$ of $(\mathrm{fppz}) \mathrm{H}$ $(0.53 \mathrm{mmol})$, and $100 \mathrm{mg}$ of $\mathrm{Na}_{2} \mathrm{CO}_{3}(0.94 \mathrm{mmol})$ in $20 \mathrm{~mL}$ of 2-methoxyethanol. Black crystals of $\left[(\mathrm{dtpz})_{2} \operatorname{Ir}(\mathrm{fppz})\right](\mathbf{4})$ were obtained from a mixture of $\mathrm{CH}_{2} \mathrm{Cl}_{2}$ and methanol at RT (120 mg, $0.107 \mathrm{mmol}, 50 \%$ ).

\section{Spectral data for 4}

${ }^{1} \mathrm{H}$ NMR $\left(400 \mathrm{MHz}, \mathrm{CDCl}_{3}, 298 \mathrm{~K}\right) \delta: 8.69(\mathrm{~s}, 1 \mathrm{H}), 8.57$ $\left(\mathrm{d}, 1 \mathrm{H}, J_{\mathrm{HH}}=8.0 \mathrm{~Hz}\right), 8.49(\mathrm{~s}, 1 \mathrm{H}), 8.44(\mathrm{~s}, 1 \mathrm{H}), 7.98(\mathrm{~s}$, $1 \mathrm{H}), 7.91\left(\mathrm{~d}, 1 \mathrm{H}, J_{\mathrm{HH}}=8.0 \mathrm{~Hz}\right), 7.86\left(\mathrm{~d}, 1 \mathrm{H}, J_{\mathrm{HH}}=8.0 \mathrm{~Hz}\right)$, $7.81\left(\mathrm{~d}, 2 \mathrm{H}, J_{\mathrm{HH}}=5.2 \mathrm{~Hz}\right), 7.72\left(\mathrm{~d}, 1 \mathrm{H}, J_{\mathrm{HH}}=8.0 \mathrm{~Hz}\right), 7.54$ $\left(\mathrm{t}, 1 \mathrm{H}, J_{\mathrm{HH}}=1.2 \mathrm{~Hz}\right), 7.50-7.41(\mathrm{~m}, 5 \mathrm{H}), 7.40\left(\mathrm{t}, 3 \mathrm{H}, J_{\mathrm{HH}}=\right.$ $1.2 \mathrm{~Hz}), 7.31-7.24(\mathrm{~m}, 4 \mathrm{H}), 7.20-7.12(\mathrm{~m}, 3 \mathrm{H}), 6.63(\mathrm{~s}, 1 \mathrm{H})$, $6.57\left(\mathrm{~d}, 1 \mathrm{H}, J_{\mathrm{HH}}=8.0 \mathrm{~Hz}\right), 6.48\left(\mathrm{~d}, 1 \mathrm{H}, J_{\mathrm{HH}}=8.0 \mathrm{~Hz}\right), 6.44$ (s, 1H), $6.20(\mathrm{~s}, 1 \mathrm{H}), 2.54(\mathrm{~s}, 3 \mathrm{H}), 2.51(\mathrm{~s}, 3 \mathrm{H}), 1.86(\mathrm{~s}, 3 \mathrm{H})$, $1.79(\mathrm{~s}, 3 \mathrm{H})$. MS (FAB, $\left.{ }^{193} \mathrm{Ir}\right) \mathrm{m} / \mathrm{z}: 1123\left[\mathrm{M}^{+}\right]$. Anal. calcd. for $\mathrm{C}_{61} \mathrm{H}_{43} \mathrm{~F}_{3} \mathrm{IrN}_{7}$ : $\mathrm{N}$ 8.73, C 65.23, $\mathrm{H}$ 3.86; found: $\mathrm{N} 8.64, \mathrm{C}$ $64.89, \mathrm{H} 3.81$.

\section{Preparation of $\left[(\mathrm{dtbq})_{2} \operatorname{Ir}(\right.$ acac $\left.)\right](5)$}

A mixture of $\left[(\mathrm{dtbq})_{2} \mathrm{IrCl}\right]_{2}(200 \mathrm{mg}, 0.106 \mathrm{mmol})$, acetylacetone (acacH, $300 \mathrm{mg}, 3.0 \mathrm{mmol}$ ), and $\mathrm{Na}_{2} \mathrm{CO}_{3}$ (100 mg, $0.94 \mathrm{mmol})$ in $\mathrm{CH}_{2} \mathrm{Cl}_{2}(20 \mathrm{~mL})$ was stirred at RT for $24 \mathrm{~h}$. After stopping the reaction, the solution was washed with water $(3 \times 50 \mathrm{~mL})$, dried over $\mathrm{MgSO}_{4}$, and concentrated to dryness. Black crystals of $\left[(\mathrm{dtbq})_{2} \operatorname{Ir}(\mathrm{acac})\right](\mathbf{5})$ were recrystallized from $\mathrm{CH}_{2} \mathrm{Cl}_{2}$ and hexane at RT $(90 \mathrm{mg}$, $0.89 \mathrm{mmol}, 42 \%)$.

\section{Spectral data for 5}

${ }^{1} \mathrm{H}$ NMR (400 MHz, $\left.\mathrm{CDCl}_{3}, 298 \mathrm{~K}\right) \delta: 8.84(\mathrm{~s}, 2 \mathrm{H}), 8.65$ $(\mathrm{s}, 2 \mathrm{H}), 8.03\left(\mathrm{~d}, 2 \mathrm{H}, J_{\mathrm{HH}}=8.0 \mathrm{~Hz}\right), 7.94-7.89(\mathrm{~m}, 6 \mathrm{H})$, $7.49-7.42(\mathrm{~m}, 8 \mathrm{H}), 7.06\left(\mathrm{~d}, 2 \mathrm{H}, J_{\mathrm{HH}}=8.4 \mathrm{~Hz}\right), 6.41(\mathrm{~d}, 2 \mathrm{H}$, $\left.J_{\mathrm{HH}}=8.4 \mathrm{~Hz}\right), 6.32(\mathrm{~s}, 2 \mathrm{H}), 4.63(\mathrm{~s}, 1 \mathrm{H}), 2.52(\mathrm{~s}, 6 \mathrm{H}), 1.79$ $(\mathrm{s}, 6 \mathrm{H}), 1.61(\mathrm{~s}, 6 \mathrm{H})$. MS (FAB, $\left.{ }^{193} \mathrm{Ir}\right) \mathrm{m} / z: 1010\left[\mathrm{M}^{+}\right]$. Anal. calcd. for $\mathrm{C}_{57} \mathrm{H}_{45} \mathrm{IrN}_{4} \mathrm{O}_{2}$ : N 5.55, C 67.77, $\mathrm{H} 4.49$; found: $\mathrm{N}$ 5.51, C 67.63, H 4.83 .

\section{$\mathrm{X}$-ray structural analysis}

Single crystal X-ray diffraction data were measured on a Bruker Smart CCD diffractometer using (Mo K $\alpha$ ) radiation $(\lambda=0.71073 \AA$ ). The data collection was executed using the SMART program. Cell refinement and data reduction were made with the SAINT program. The structure was determined using the SHELXTL/PC program and refined using full-matrix least-squares. All non-hydrogen atoms were refined anisotropically, whereas hydrogen atoms were placed at the calculated positions and included in the final stage of refinements with fixed parameters. The crystallographic refinement parameters for complexes $\mathbf{1}$ and $\mathbf{3}$ are summarized in Table 1, and selected bond distances and angles of these complexes are listed in Tables 2 and 3, respectively. 
Table 1. Crystal data and refinement parameters for complexes $\mathbf{1}$ and $\mathbf{3}$.

\begin{tabular}{|c|c|c|}
\hline Compound & 1 & 3 \\
\hline Formula & $\mathrm{C}_{57} \mathrm{H}_{35} \mathrm{~F}_{3} \mathrm{~N}_{7} \mathrm{Ir} \cdot \mathrm{CH}_{2} \mathrm{Cl}_{2}$ & $\mathrm{C}_{58} \mathrm{H}_{38} \mathrm{~N}_{6} \mathrm{Ir} \cdot \mathrm{BF}_{4} \cdot \mathrm{CH}_{2} \mathrm{Cl}_{2}$ \\
\hline Molecular weight & 1152.05 & 1182.88 \\
\hline Crystal system & Triclinic & Triclinic \\
\hline Space group & $P-1$ & $P-1$ \\
\hline Crystal size $\left(\mathrm{mm}^{3}\right)$ & $0.4 \times 0.15 \times 0.12$ & $0.18 \times 0.15 \times 0.05$ \\
\hline$a(\AA)$ & $11.9568(4)$ & $16.3626(6)$ \\
\hline$b(\AA)$ & $12.0739(5)$ & $17.2949(6)$ \\
\hline$c(\AA)$ & $17.1667(7)$ & $19.5430(7)$ \\
\hline$\alpha\left(^{\circ}\right)$ & $74.820(1)$ & $73.631(1)$ \\
\hline$\beta\left(^{\circ}\right)$ & $82.535(1)$ & $72.197(1)$ \\
\hline$\gamma\left({ }^{\circ}\right)$ & $84.788(1)$ & $70.003(1)$ \\
\hline$V\left(\AA^{3}\right)$ & $2367.4(2)$ & $4850.1(3)$ \\
\hline$Z$ & 2 & 4 \\
\hline$\rho_{\text {calcd }}\left(\mathrm{g} \mathrm{cm}^{-3}\right)$ & 1.616 & 1.620 \\
\hline Temp $(\mathrm{K})$ & $295(2)$ & $150(1)$ \\
\hline$\mu\left(\mathrm{mm}^{-1}\right)$ & 2.994 & 2.927 \\
\hline Reflections collected & 31690 & 64361 \\
\hline Independent reflections & $10878(R($ int $)=0.0419)$ & $22242(R$ (int $)=0.0680)$ \\
\hline$R_{F}, R_{w}\left(F^{2}\right)$ (all data) & $0.0445,0.0928$ & $0.0873,0.1475$ \\
\hline$R_{F}, R_{w}\left(F^{2}\right)[\mathrm{I}>2 \sigma(\mathrm{I})]$ & $0.0360,0.0860$ & $0.0606,0.1319$ \\
\hline GOF & 1.043 & 1.144 \\
\hline
\end{tabular}

Note: $R_{F}=\Sigma|| F_{\mathrm{o}}-F_{\mathrm{c}}|| / \Sigma\left|F_{\mathrm{o}}\right|$ and $R_{w}\left(F^{2}\right)=\left[\Sigma w\left|F_{\mathrm{o}}^{2}-F_{\mathrm{c}}{ }^{2}\right|^{2} / \Sigma w\left(F_{\mathrm{o}}^{4}\right)\right]^{1 / 2}$.

Table 2. Selected bond lengths $(\AA)$ and angles $\left({ }^{\circ}\right)$ for complex $\mathbf{1}$.

\begin{tabular}{lc}
\hline Bond lengths $(\AA)$ & \\
$\mathrm{Ir}-\mathrm{N}(1)$ & $2.201(3)$ \\
$\mathrm{Ir}-\mathrm{N}(4)$ & $2.065(3)$ \\
$\mathrm{Ir}-\mathrm{C}(10)$ & $1.990(4)$ \\
$\mathrm{C}(25) \cdots \mathrm{N}(2)$ & $3.013(7)$ \\
$\mathrm{C}(49) \cdots \mathrm{N}(1)$ & $3.165(6)$ \\
$\mathrm{Ir}-\mathrm{N}(2)$ & $2.116(3)$ \\
$\mathrm{Ir}-\mathrm{N}(6)$ & $2.047(3)$ \\
$\mathrm{Ir}-\mathrm{C}(34)$ & $1.991(4)$ \\
$\mathrm{C}(25) \cdots \mathrm{N}(3)$ & $3.381(6)$ \\
$\mathrm{C}(49) \cdots \mathrm{C}(1)$ & $3.439(6)$ \\
$\mathrm{Bond}$ angles $\left(^{\circ}\right)$ & \\
$\mathrm{N}(1)-\mathrm{Ir}-\mathrm{N}(2)$ & \\
$\mathrm{N}(6)-\mathrm{Ir}-\mathrm{C}(34)$ & $75.02(13)$ \\
$\mathrm{N}(2)-\mathrm{Ir}-\mathrm{C}(10)$ & $79.47(15)$ \\
$\mathrm{N}(4)-\mathrm{Ir}-\mathrm{C}(10)$ & $174.19(14)$ \\
$\mathrm{N}(1)-\mathrm{Ir}-\mathrm{C}(34)$ & $79.21(15)$ \\
$\mathrm{N}(4)-\mathrm{Ir}-\mathrm{N}(6)$ & $170.85(14)$ \\
\hline
\end{tabular}

The crystallographic data for complexes $\mathbf{1}$ and $\mathbf{3}$ (excluding structure factors) have been deposited. ${ }^{5}$

\section{Spectral and dynamic measurement}

Steady-state absorption and emission spectra were re-
Table 3. Selected bond lengths $(\AA)$ and angles $\left({ }^{\circ}\right)$ for complex 3 .

\begin{tabular}{lr}
\hline Bond lengths $(\AA)$ & \\
$\operatorname{Ir}(1)-\mathrm{N}(1)$ & $2.062(6)$ \\
$\operatorname{Ir}(1)-\mathrm{N}(5)$ & $2.171(6)$ \\
$\operatorname{Ir}(1)-\mathrm{C}(1)$ & $1.992(7)$ \\
$\mathrm{C}(23) \cdots \mathrm{N}(6)$ & $2.995(8)$ \\
$\mathrm{C}(47) \cdots \mathrm{N}(5)$ & $3.146(9)$ \\
$\operatorname{Ir}(1)-\mathrm{N}(3)$ & $2.076(5)$ \\
$\operatorname{Ir}(1)-\mathrm{N}(6)$ & $2.160(6)$ \\
$\operatorname{Ir}(1)-\mathrm{C}(25)$ & $1.999(6)$ \\
$\mathrm{C}(23) \cdots \mathrm{C}(58)$ & $3.336(8)$ \\
$\mathrm{C}(47) \cdots \mathrm{C}(49)$ & $3.438(8)$ \\
$\mathrm{Bond}$ angles $\left(^{\circ}\right)$ & \\
$\mathrm{N}(1)-\operatorname{Ir}(1)-\mathrm{C}(1)$ & \\
$\mathrm{N}(5)-\operatorname{Ir}(1)-\mathrm{N}(6)$ & $79.4(3)$ \\
$\mathrm{N}(6)-\operatorname{Ir}(1)-\mathrm{C}(1)$ & $75.2(2)$ \\
$\mathrm{N}(3)-\operatorname{Ir}(1)-\mathrm{C}(25)$ & $171.7(2)$ \\
$\mathrm{N}(1)-\operatorname{Ir}(1)-\mathrm{N}(3)$ & $79.3(2)$ \\
$\mathrm{N}(5)-\operatorname{Ir}(1)-\mathrm{C}(25)$ & $173.7(2)$ \\
\hline
\end{tabular}

\footnotetext{
${ }^{5}$ Supplementary data for this article are available on the journal Web site (http://canjchem.nrc.ca) or may be purchased from the Depository of Unpublished Data, Document Delivery, CISTI, National Research Council Canada, Ottawa, ON K1A 0R6, Canada. DUD 5002. For more information on obtaining material refer to http://cisti-icist.nrc-cnrc.gc.ca/irm/unpub_e.shtml. CCDC 276875 and 276876 contain the crystallographic data for this manuscript. These data can be obtained, free of charge, via http://www.ccdc.cam.ac.uk/conts/retrieving.html (Or from the Cambridge Crystallographic Data Centre, 12 Union Road, Cambridge CB2 1EZ, UK; fax +44 1223 336033; or deposit@ccdc.cam.ac.uk).
} 
a mechanic chopper operated at $200 \mathrm{~Hz}$. To minimize the reabsorption effect, the excitation beam was focused as closely as possible to the front wall of the quartz cell. The NIR emission was measured by the photomultiplier tube (Hamamatzu R5509-72, operated at $-80{ }^{\circ} \mathrm{C}$ ) coupled with a Lock-in amplifier (SR830, Stanford Research Systems, Sunnyvale, California) and a monochromator (SpectraPro275, Acton Research Corporation, Acton, Massachusetts) in that the grating was blazed at $1200 \mathrm{~nm}$. IR125 (Exciton Inc., Dayton, Ohio) with $\Phi \sim 0.11\left(\lambda_{\max } \sim 925 \mathrm{~nm}\right)$ in DMSO solution was used as a standard to calculate the emission quantum yield (10). For the NIR lifetime measurement, the sample was excited by a $532 \mathrm{~nm}$ pulse (2nd harmonic of $\mathrm{Nd}: Y A G, 6 \mathrm{~ns})$. The emission trace was detected by a photomultiplier tube (Hamamatzu R5509-72) operated at $-80{ }^{\circ} \mathrm{C}$ and recorded by a sampling oscilloscope (TDS 3012, Tektronix, Beaverton, Oregon). An average of 100 shots was taken in the lifetime measurement, unless specified elsewhere.

\section{Computational methodology}

Calculations on the electronic ground state of complexes $\mathbf{1}$ and 3 were carried out using B3LYP density functional theory $(11,12)$. A double- $\zeta$ quality basis set consisting of Hay and Wadt's effective core potentials (LANL2DZ) (13) was employed for the Ir atom and a 6-31G* (14) basis for the H, $\mathrm{C}, \mathrm{N}$, and $\mathrm{F}$ atoms. A relativistic effective core potential (ECP) replaced the inner core electrons of $\operatorname{Ir}(\mathrm{III})$, leaving the outer core $\left(5 s^{2} 5 p^{6}\right)$ electrons and the $5 d^{6}$ valence electrons. Time-dependent DFT (TDDFT) calculations (15) using the B3LYP functional were then performed based on the structural optimized geometries. Typically, the lowest 10 triplet and 10 singlet roots of the nonhermitian eigenvalue equations were obtained to determine the vertical excitation energies. Oscillator strengths were deduced from the dipole transition matrix elements (for singlet states only). The ground-state B3LYP and excited-state TDDFT calculations were carried out using Gaussian03 (16).

\section{Results and discussion}

\section{Syntheses and structural characterization}

The preparation of highly conjugated ligand chromophores is necessary to achieve the NIR-emitting iridium complexes. As depicted in Scheme 1, the required ligands can be synthesized by treatment of 2,3-naphthalenediamine and dibenzil to produce 2,3-diphenyl-or di-p-tolyl-substituted benzo[ $g]$ quinoxaline in good yields. This synthetic approach follows the literature procedure utilized for the analogous diphenylquinoxaline, and is best prepared from related $o$ phenylenediamine and the corresponding $\alpha$-diketone in refluxing ethanol (17).

Subsequent reactions of $\mathrm{IrCl}_{3} \cdot n \mathrm{H}_{2} \mathrm{O}$ with (dpbq)H or (dtbq) $\mathrm{H}$ in refluxing ethoxyethanol afforded chloride-bridged dimers $\left[(\mathrm{dpbq})_{2} \mathrm{IrCl}\right]_{2}$ or $\left[(\mathrm{dtbq})_{2} \mathrm{IrCl}\right]_{2}$, respectively. These dimer complexes can easily react with the pyrazole chelate ligand (fppz)H in the presence of $\mathrm{Na}_{2} \mathrm{CO}_{3}$ to afford blackcolored complexes $\left[(\mathrm{dpbq})_{2} \operatorname{Ir}(\mathrm{fppz})\right](\mathbf{1})$ and $\left[(\mathrm{dtbq})_{2} \operatorname{Ir}(\mathrm{fppz})\right]$ (4), where (fppz)H = 3-trifluoromethyl-5-(2-pyridyl)pyrazole. Similar reactions towards other bidentate chelates such as 1-(5-tert-butyl-2H-pyrazol-3-yl)isoquinoline ((bpiq)H), 2,2' -
Scheme 1.

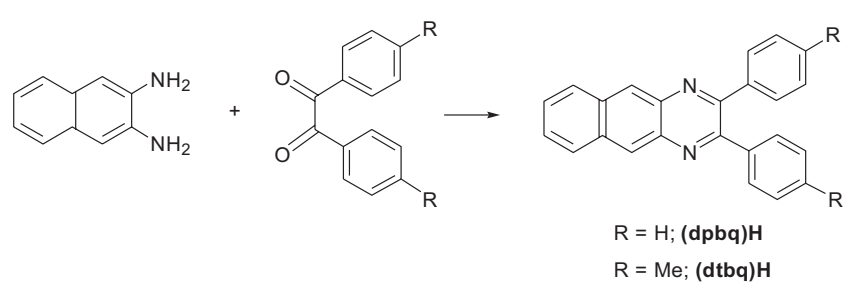

Scheme 2.
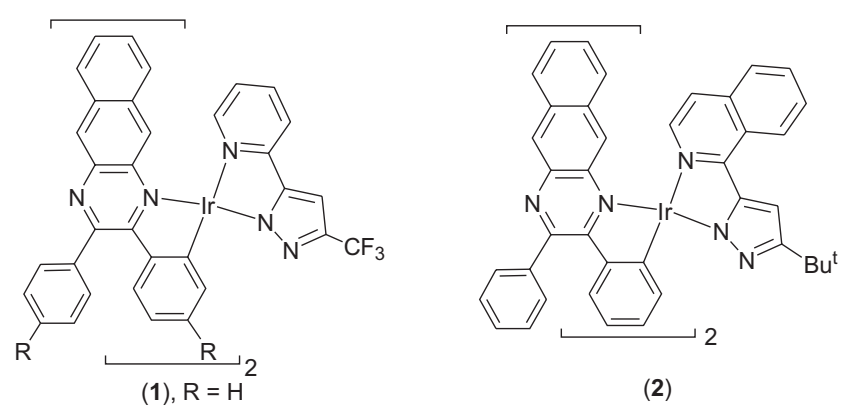

(4), $R=M e$

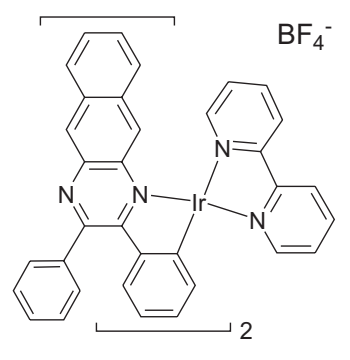

(3)
(2)

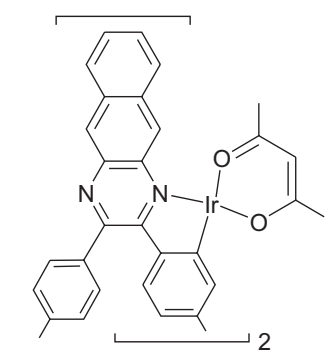

(5) bipyridine (bpy), and acetylacetone $(\mathrm{acacH})$ yielded the corresponding $\operatorname{Ir}(\mathrm{III})$ complexes, $\left[(\mathrm{dpbq})_{2} \operatorname{Ir}(\mathrm{bpiq})\right] \quad$ (2), $\left[(\mathrm{dpbq})_{2} \operatorname{Ir}(\mathrm{bpy})\right]\left[\mathrm{BF}_{4}\right](\mathbf{3})$, and $\left[(\mathrm{dtbq})_{2} \operatorname{Ir}(\mathrm{acac})\right](\mathbf{5})$, respectively (see Scheme 2).

All iridium complexes were easily soluble in organic solvents such as $\mathrm{CH}_{2} \mathrm{Cl}_{2}$, THF, and acetone, and the corresponding solutions showed negligible decomposition for a period of over $24 \mathrm{~h}$, upon exposure to air. Routine characterizations were conducted using microanalysis, mass spectrometry, and ${ }^{1} \mathrm{H}$ NMR spectroscopy. Moreover, the fppz complex 1 was further characterized by single crystal X-ray diffraction analysis. Its ORTEP diagram is depicted in Fig. 1, while crucial bond distances and angles are listed in Table 1.

As depicted in Fig. 1, complex 1 reveals a distorted octahedral geometry around the Ir atom, consisting of two cyclometalated phenylbenzoquinoxaline fragments and one (2pyridyl) pyrazolate ligand. The unique pyrazolate chelate is located opposite to the cis-oriented carbon donor atoms of benzoquinoxaline, while the benzoquinoxaline ligands adopt an eclipse configuration and their coordinated nitrogen atoms (N(4) and $\mathrm{N}(6))$ and carbon atoms $(\mathrm{C}(10)$ and $\mathrm{C}(34))$ adopt trans and cis orientation, respectively. This coordinative arrangement is akin to those of the parent phenyl pyridine ligands observed for the chloride-bridged dimer 
Fig. 1. (a) ORTEP diagram of $\mathbf{1}$ with thermal ellipsoids shown at the $30 \%$ probability level; fluorine atoms of the $\mathrm{CF}_{3}$ substituent were omitted for clarity. (b) Same ORTEP diagram with an emphasis on the spatial distortion of dpbq ligands.
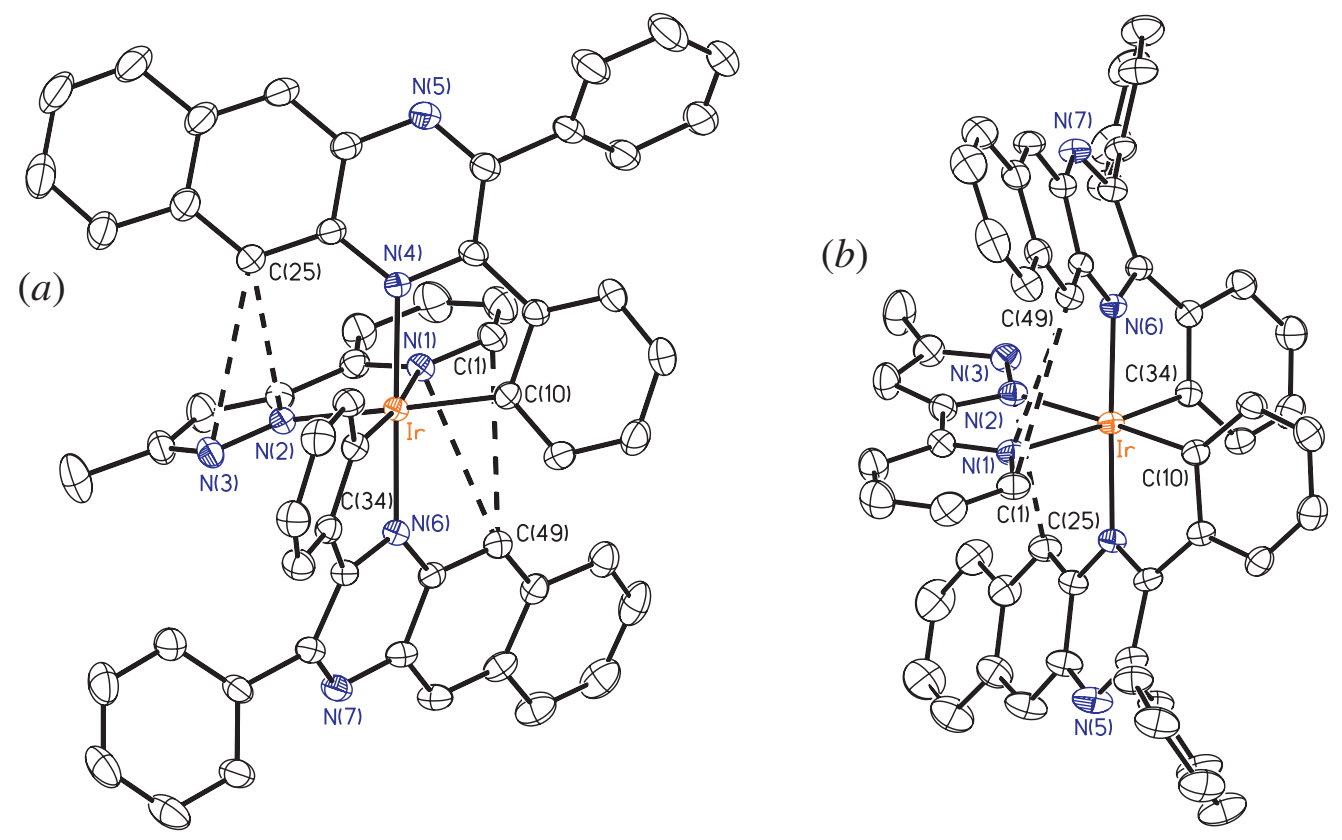

complex $\left[(\mathrm{ppy})_{2} \operatorname{Ir}(\mu-\mathrm{Cl})\right]_{2}$ (18), the diketonate complex (ppy) $)_{2} \operatorname{Ir}(\mathrm{acac})(19)$, and even the pyrazolate derivatives, suggesting that the incoming fppz ligand occupies the positions of the bridging chloride ligands in its starting material, $\left[(\mathrm{dpbp})_{2} \mathrm{IrCl}\right]_{2}$. Moreover, the uncoordinated and cyclometalated phenyl groups show twisting angles of $40^{\circ}-54^{\circ}$, as well as unusually large deformation angles of $23^{\circ}-28^{\circ}$ with respect to the middle benzoquinoxaline fragments. The deformation angles reveal an unfavorable steric interaction between the chelating ligands and can be gauged by the least-squares calculation using planes defined by the cyclometalated phenyl group and the middle $\mathrm{C}_{6}$ hexagon of the benzoquinoxaline. It appears to us that the nonbonding repulsion between benzoquinoxaline and pyridyl pyrazolate ligands is the main driving force causing such a large distortion at the cyclometalated phenyl groups, as most of the interligand $\mathrm{C} \cdots \mathrm{C}$ and $\mathrm{C} \cdots \mathrm{N}$ nonbonding contacts listed in Table 2 are shorter than a limited value of ca. $3.4 \AA$, i.e., the sum of the van der Waals radii of the carbon atoms.

For a further comparison, the X-ray structural study on the cationic dipyridine complex 3 was also examined. Comparison of the ORTEP diagram (Fig. 2) and the metric parameters (Table 3) with those of $\mathbf{1}$ shows no significant variation on the overall molecular architecture, except for the formation of an approximate $\mathrm{C}_{2}$ rotational axis that bisects the bipyridine ligand and passes through the central Ir metal atom. This increasing molecular symmetry is consistent with the simplification of the ${ }^{1} \mathrm{H}$ NMR spectral pattern observed in solution at RT (see the Experimental section).

\section{Electrochemistry}

The electrochemical properties of these Ir complexes were investigated by $\mathrm{CV}$ using ferrocene as the internal standard, and the respective redox data are listed in Table 4. During the anodic scan, all iridium complexes exhibited a reversible oxidation wave with potentials in the region $0.50-0.77 \mathrm{~V}$. It is believed that the oxidation process mainly occurred at the metal center and, in part, with a slight contribution from the surrounding chelate ligands (20). Thus, the formal oxidation potential was strongly dependent on the electronic environment of the $\operatorname{Ir}(\mathrm{III})$ cation, i.e., a better electron donor would shift the oxidation potential to a less positive value. This hypothesis was verified by the increased $\pi$ conjugation of the anionic bpiq ligand in $\mathbf{2}$, which decreased the oxidative potential from 0.77 (in 1) to $0.61 \mathrm{~V}$ (in 2), while the attachment of the 2,2'-bipyridine ligand in $\mathbf{3}$ led to the complete suppression of the metal oxidation signal owing to its cationic nature. Moreover, replacement of the phenyl substituents with tolyl substituents of benzoquinoxaline also slightly altered the oxidation potential, as supported by the fact that the oxidation potential of $\mathbf{4}$ is cathodically shifted to $0.70 \mathrm{~V}$ in comparison with that of the parent complex $\mathbf{1}$. Owing to the presence of an extra methyl substituent, this result could possibly be attributed to a slightly better $\sigma$-donor ability of the cyclometalated tolyl group.

Upon switching to the cathodic sweep in THF, two reversible reduction processes, with potentials ranging from -1.33 to $-1.96 \mathrm{~V}$, were detected for all complexes (1-5). We assigned these signals to a sequential reduction of the cyclometalated benzoquinoxaline fragments. For dtbq complex $\mathbf{4}$, the first reduction peak is shifted to $-1.65 \mathrm{~V}$ in comparison with that of the dpbq counterpart $1(-1.54 \mathrm{~V})$ because of the electron-releasing effect of the para-methyl substituents. Conversely, complex $\mathbf{3}$ showed the lowest reduction potentials, owing to its cationic nature, while complexes $\mathbf{2}$ and $\mathbf{5}$ gave the highest reduction potential among the whole series. The results indicate that the third ancillary ligand also significantly affects the redox properties of these Ir complexes, possibly via their enhanced donor capability as well as the extended $\pi$ conjugation. Qualitatively, this observation is consistent with both the photophysical properties and theoretical predictions elaborated as follows. 
Fig. 2. (a) ORTEP diagram of $\mathbf{3}$ with thermal ellipsoids shown at the $50 \%$ probability level. (b) Same ORTEP diagram with an emphasis on the spatial distortion of dpbq ligands.
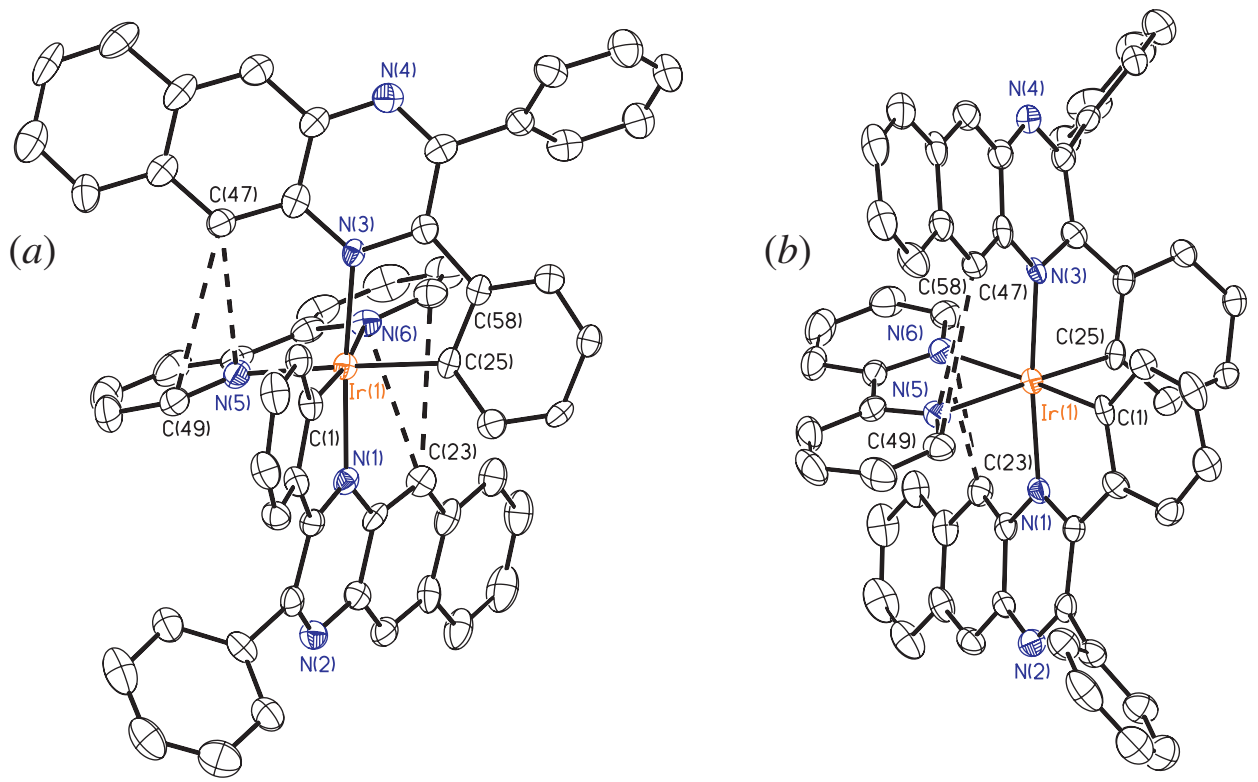

Table 4. One-electron redox potentials of complexes 1-5.

\begin{tabular}{lll}
\hline Complex & $E_{1 / 2}{ }^{\mathrm{ox}}(\mathrm{V})^{a}$ & $E_{1 / 2}{ }^{\text {red }}(\mathrm{V})^{a}$ \\
\hline $\mathbf{1}$ & $0.77[100]^{b}$ & $-1.54[110],-1.81[100]$ \\
$\mathbf{2}$ & $0.61[80]$ & $-1.64[100],-1.91[100]$ \\
$\mathbf{3}$ & - & $-1.31[80],-1.61[80]$ \\
$\mathbf{4}$ & $0.70[100]$ & $-1.65[110],-1.91[120]$ \\
$\mathbf{5}$ & $0.50[90]$ & $-1.73[90],-1.96[100]$ \\
\hline
\end{tabular}

${ }^{a}$ Potential values referenced vs. $\mathrm{Fc} / \mathrm{Fc}^{+}$.

${ }^{b}$ Data in square bracket denotes the $\left|E_{\mathrm{pa}}-E_{\mathrm{pc}}\right|$ values in $\mathrm{mV}$.

\section{Photophysical properties}

Figure 3 shows the absorption and emission spectra of complexes $\mathbf{1 - 5}$ in $\mathrm{CH}_{2} \mathrm{Cl}_{2}$. As supported by $\mathrm{CV}$ measurements as well as the frontier orbital analyses (see the following section), it is reasonable to assign the first $S_{0}-S_{1}$ transition to absorption peaks around 500-600 nm $(\varepsilon \sim 5 \times$ $\left.10^{3}(\mathrm{~mol} / \mathrm{L})^{-1} \mathrm{~cm}^{-1}\right)$ to a metal to ligand (benzoquinoxaline part) charge transfer (MLCT) overlapping with the interligand phenyl to benzoquinoxaline transition. Due to a large molecular framework, the composition of higher electronic states is complicated, so that any corresponding assignments for complexes 1-5 may not be meaningful. Furthermore, the Ir-metal-enhanced spin-orbit coupling should result in nonnegligible absorptivity for the triplet transition, as indicated by a corresponding small absorption hump around 650-700 nm. However, absorption bands ascribed to the triplet manifolds could not be distinctly resolved mainly owing to their hiding inside the UV region of the strong singlet transitions. Detailed discussion regarding the transition in the triplet manifold will be given in the Theoretical approach section.

Figure 3 also depicts the emission spectra of complexes 1-5 in $\mathrm{CH}_{2} \mathrm{Cl}_{2}$. The spectral feature, quantum efficiency and relaxation dynamics (vide infra) of complexes $\mathbf{1 - 5}$ show concentration independence up to $10^{-3} \mathrm{~mol} / \mathrm{L}$, indicating a
Fig. 3. The absorption and emission spectra of complexes 1-5 in $\mathrm{CH}_{2} \mathrm{Cl}_{2}$. The peak intensities were normalized. $\lambda_{\mathrm{ex}}=514 \mathrm{~nm}$. The arrow indicates the peak for ${ }^{1} \mathrm{O}^{2}{ }^{1} \Delta g\left(v^{\prime}=0\right) \rightarrow \Sigma_{g}{ }^{-}\left(v^{\prime \prime}=0\right)$ $1276 \mathrm{~nm}$ emission.

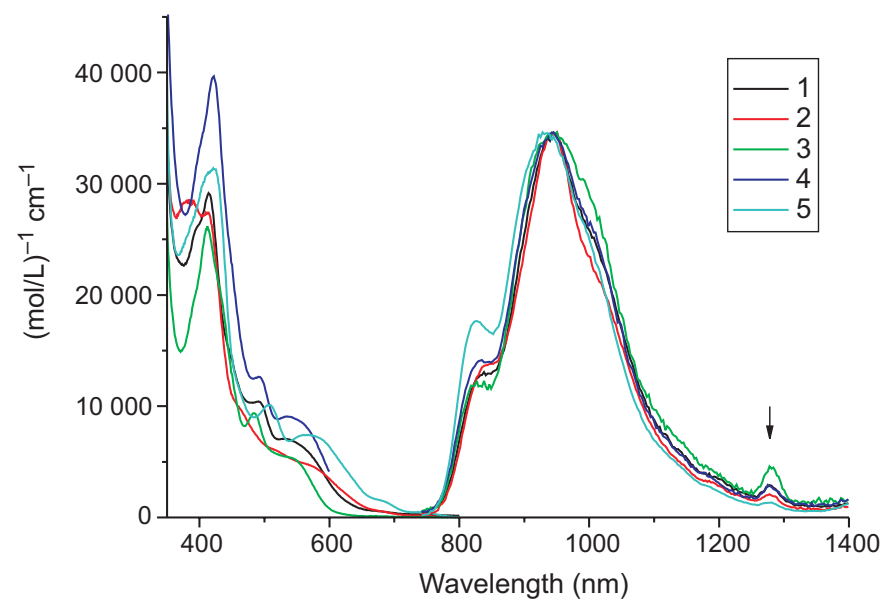

negligible aggregation effect in fluid solution. To reveal any differences in the spectral profile, the emission spectra were normalized at the peak wavelength. In comparison, for all complexes studied, only a slight variation was observed in view of the emission spectral feature and peak position. As listed in Table 5, the relaxation dynamics of $\mathbf{1 - 5}$ are $\mathrm{O}_{2}$ concentration dependent. For example, the decay time of complex 1 was measured to be 286 ns in the degassed $\mathrm{CH}_{2} \mathrm{Cl}_{2}$, while it was decreased to $200 \mathrm{~ns}$ upon aeration. In the $\mathrm{O}_{2}$ dependent study, in which the $\mathrm{O}_{2}$ concentration was monitored by its vapor pressure filled in the vacuum line and deduced by Henry's law, a straight Stern-Volmer plot could be formulated (not shown here), and an oxygen-quenching rate constant of $1.7 \times 10^{9}(\mathrm{~mol} / \mathrm{L})^{-1} \mathrm{~s}^{-1}$ was deduced, which is nearly one-nineth of the diffusion-controlled rate of $2.0 \times$ $10^{10}(\mathrm{~mol} / \mathrm{L})^{-1} \mathrm{~s}^{-1}$ calculated from the Stokes-Einstein equa- 
Table 5. Photophysical properties of complexes $\mathbf{1 - 5}$ in $\mathrm{CH}_{2} \mathrm{Cl}_{2}$ at room temperature.

\begin{tabular}{llllll}
\hline Complex & $\lambda_{\text {abs }}(\mathrm{nm})\left(\varepsilon, 10^{3}(\mathrm{~mol} / \mathrm{L})^{-1} \mathrm{~cm}^{-1}\right)$ & $\lambda_{\mathrm{em}}(\mathrm{nm})$ & $\Phi_{\mathrm{aer}}\left(\times 10^{3}\right)^{a}$ & $\tau_{\mathrm{aer}}(\mathrm{ns})$ & $\tau_{\mathrm{deg}}(\mathrm{ns})$ \\
\hline $\mathbf{1}$ & $535(7), 491(10), 414(29)$ & 916 & 6.48 & 200 & 286 \\
$\mathbf{2}$ & $575(5), 464(10), 414(27)$ & 922 & 9.53 & 195 & 276 \\
$\mathbf{3}$ & $540(5), 484(9), 412(26)$ & 922 & 3.59 & 245 & 403 \\
$\mathbf{4}$ & $541(9), 491(13), 422(40)$ & 916 & 10.2 & 209 & 302 \\
$\mathbf{5}$ & $570(7), 508(10), 421(31)$ & 904 & 21.8 & 216 & 290 \\
\hline
\end{tabular}

${ }^{a}$ Quantum efficiencies were measured in aerated $\mathrm{CH}_{2} \mathrm{Cl}_{2}$.

Fig. 4. HOMO and LUMO of complex 1 involved in the low-lying transition.

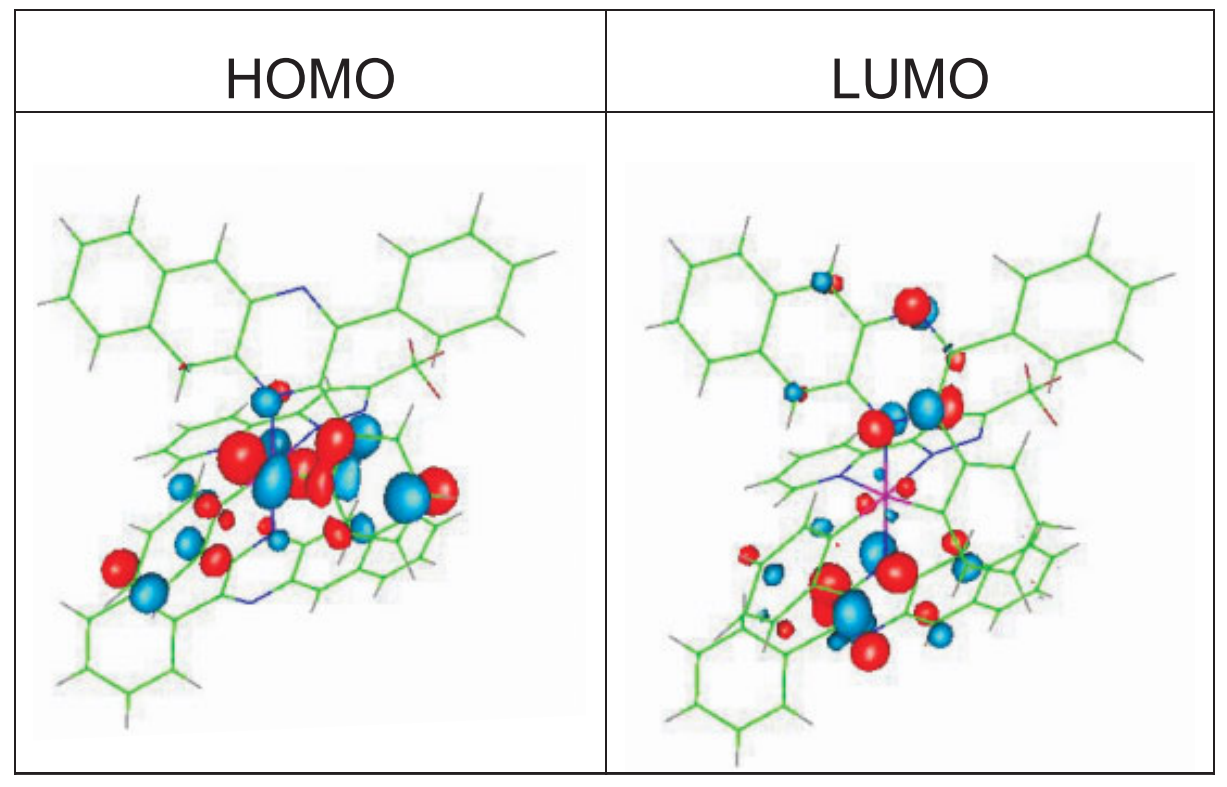

Table 6. The calculated lowest excited singlet and triplet states of complex $\mathbf{1}$.

\begin{tabular}{lllll}
\hline State & Assignment & $\lambda(\mathrm{nm})$ & $E(\mathrm{eV})$ & $f$ \\
\hline $\mathrm{S}_{1}$ & HOMO $\rightarrow$ LUMO (+95\%) & 618.3 & 2.01 & 0.0067 \\
$\mathrm{~T}_{1}$ & HOMO-1 $\rightarrow$ LUMO (+42\%) & 743.6 & 1.67 & $\sim 0$ \\
& HOMO $\rightarrow$ LUMO (+37\%) & & \\
& HOMO-1 $\rightarrow$ LUMO+1 $(23 \%)$ & & & \\
& HOMO-2 $\rightarrow$ LUMO (11\%) & & \\
\hline
\end{tabular}

tion in $\mathrm{CH}_{2} \mathrm{Cl}_{2}$. The result is consistent with the $\mathrm{O}_{2}$-quenching triplet state according to the theory of electron-exchange type (Dexter type) of energy transfer expressed as (21):

$$
\mathrm{T}+{ }^{3} \mathrm{O}_{2} \stackrel{k_{\mathrm{O}_{2}}}{\longrightarrow} \mathrm{S}_{0}+{ }^{1} \mathrm{O}_{2}
$$

The overall spin must be conserved upon forming a collisional complex. Accordingly, the possibility of each collision producing ${ }^{1} \mathrm{O}_{2}$ is statistically one-nineth. Perhaps the strongest support for the $\mathrm{O}_{2}$ quenching is given by the observation of ${ }^{1} \mathrm{O}_{2}\left({ }^{1} \Delta_{\mathrm{g}}\left(v^{\prime \prime}=0\right) \rightarrow{ }^{1} \Sigma^{-}{ }_{\mathrm{g}}\left(v^{\prime}=0\right)\right.$ emission with a peak wavelength at $\sim 1276 \mathrm{~nm}$ (22) for complexes 1-5 in aerated $\mathrm{CH}_{2} \mathrm{Cl}_{2}$ (see the arrow in Fig. 3). The results, in combination with the rather small radiative decay rate of $<10^{6} \mathrm{~s}^{-1}$, lead us to unambiguously assign the dominant emission in complexes 1-5 to be of phosphorescence character. The spectra show a distinctly $0-0$ vibronic onset of the transition, a profile that normally appears in a ${ }^{3} \pi-\pi^{*}$ transition of aromatic chromophores with high symmetry. The results pro- vide a clue that the observed phosphorescence possesses, in part, a ${ }^{3} \pi-\pi^{*}$ character plausibly originating from a ligandcenter chromophore of long conjugation such as benzoquinoxaline. Nevertheless, the involvement of other transitions such as ${ }^{3}$ MLCT is also possible. Furthermore, the observation of rather small changes in spectral features, as well as peak positions, implies that frontier orbitals responsible for the $T_{1}-S_{0}$ transition may be mainly derived from the same origin for complexes $\mathbf{1 - 5}$. It is thus of fundamental importance to gain more detailed insights into the transition properties of the phosphorescence based on the theoretical approaches elaborated as follows.

\section{Theoretical approach}

Theoretical confirmation of the photophysical properties of complex 1 was provided by the DFT calculations. In this study, the crystallographic data for $\mathbf{1}$ was used as the framework for the extended Hückel formalism, and the calculation 
was performed via a CACAO program (see the Experimental section). Figure 4 depicts the features of the HOMO to HOMO-3 and LUMO to LUMO+3 frontier orbitals mainly involved in the lower-lying transition, while the descriptions and the energy gaps of each transition are listed in Table 6. The validity of the TDDFT approach can be readily perceived by the calculated $\mathrm{T}_{1} \rightarrow \mathrm{S}_{0}$ emission peak at $745 \mathrm{~nm}$, which is very close to the $0-0$ onset peak $(\sim 785 \mathrm{~nm})$ observed experimentally. Based on the results (see Fig. 4 and Table 6), the electron densities of the HOMO are mainly located on the $\operatorname{Ir}(\mathrm{III})$ metal center and, to a small extent, the cyclometalated phenyl ligand, while a large portion of the electron densities of HOMO-1 and HOMO-2 is attributed to the $\pi$ orbitals of benzoquinoxaline overlapping with certain $\mathrm{d}_{\pi}$ orbitals of the $\operatorname{Ir}(\mathrm{III})$ atom. Conversely, the electron densities of LUMO and LUMO+1 are distributed mostly on the benzoquinoxaline moiety. The $\mathrm{S}_{0} \rightarrow \mathrm{S}_{1}$ and $\mathrm{S}_{0} \rightarrow \mathrm{S}_{2}$ transitions mainly incorporate HOMO $\rightarrow$ LUMO (+95\%) and $\mathrm{HOMO} \rightarrow \mathrm{LUMO}+1(+93 \%)$, respectively, and thus are dominated by MLCT $\left(\mathrm{d}_{\pi}\right.$ (Ir) $\rightarrow \pi^{*}$ (benzoquinoxaline)) overlapping with $\pi-\pi^{*}$ ILCT (mainly cyclometalated phenyl site $(\pi) \rightarrow$ benzoquinoxaline pyridine site $\left.\left(\pi^{*}\right)\right)$ in character. As supported by the data shown in Table 6, the higher excited states in the singlet manifold, $\mathrm{S}_{0} \rightarrow \mathrm{S}_{n}(n>3)$, are relatively much more complicated, the results of which make a definitive frontier orbital assignment meaningless. In contrast, the lowest electronic transition in the triplet manifold, i.e., $S_{0} \rightarrow T_{1}$, mainly incorporates the ligand center benzoquinoxaline ${ }^{3} \pi-\pi^{*}$ transition and ${ }^{3} \operatorname{MLCT}\left(\mathrm{d}_{\pi}(\mathrm{Ir}) \rightarrow \pi^{*}\right.$ (benzoquinoxaline)).

The contribution of the ${ }^{3} \pi-\pi^{*}$ transition is manifested by the low-temperature $(77 \mathrm{~K})$ approach to complex $\mathbf{1}$. Figure 5 shows the luminescence spectrum of 1 in a $77 \mathrm{~K} \mathrm{CH}_{2} \mathrm{Cl}_{2}$ matrix. Two salient remarks can be pointed out promptly according the spectral layout. First, in comparison to that measured at $298 \mathrm{~K}$, the enhancement of the vibronic progression at $77 \mathrm{~K}$ is obvious, showing the notable population switching from perhaps ${ }^{3} \mathrm{MLCT} /{ }^{3} \pi-\pi$ mixing character to the ${ }^{3} \pi-\pi$ dominating state under this condition. Nevertheless, one cannot eliminate the possibility that the increase in vibronic resolution upon cooling may just indicate an increase in rigidity of the molecule, making the vibrational levels more identical to one another, as well as the disappearance of hot bands. Secondly, the phosphorescence intensity at $77 \mathrm{~K}$ is increased $\sim 2.5$-fold with respect to that at 298 K. Similar structural phosphorescence with 2- to $\sim 3$-fold increases in intensity was observed for complexes $\mathbf{2}-\mathbf{5}$ in $77 \mathrm{~K} \mathrm{CH}_{2} \mathrm{Cl}_{2}$. Thus, temperature-dependent radiationless deactivation pathways may only play a minor role to the relaxation dynamics. Moreover, as listed in Table 5, substitution at non-benzoquinoxaline sites causes neither spectral change nor large alternation of the quantum efficiency. The latter implies that the large amplitude vibration or any torsional motion at nonbenzoquinoxaline sites, which generally quenches emission in the NIR region, are not actively involved in the deactivation process. This viewpoint can be rationalized by the negligible contribution of non-benzoquinoxaline ligands to both HOMO (or HOMO-1 and HOMO-2) and LUMO (or LUMO+1). Since complexes $\mathbf{1 - 5}$ all bear aryl substituents at benzoquinoxaline sites, it is plausible that the torsional motion of phenyl (or tolyl) substituents, the relaxation dynam-
Fig. 5. The luminescence spectrum of $\mathbf{1}$ at room temperature ( $\mathbf{\square})$ and in the $77 \mathrm{~K} \mathrm{CH}_{2} \mathrm{Cl}_{2}$ matrix $(\Delta)$. Note that both spectra were analyzed using the same absorbance and excitation wavelength $(514 \mathrm{~nm})$. Thus, the intensity ratio can be directly estimated from the spectral integration.

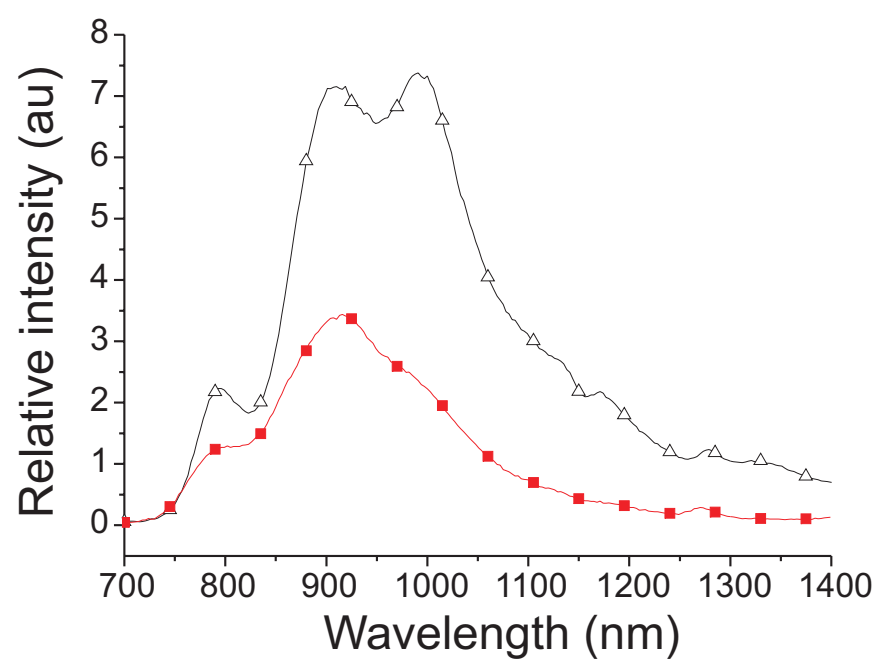

ics of which should be temperature dependent, partly induces the radiationless transition. However, one ought to realize that because of the much smaller NIR energy gap, excitation that causes any weakening of the bond strength may result in crossing of the potential energy surface between $T_{1}$ and $S_{0}$ states and eventually trigger the rapid radiationless deactivation. In the case of complexes $\mathbf{1 - 5}$, these nearly temperatureindependent, weak vibrational motions play a key role in accounting for the dominant radiationless deactivation.

\section{Conclusion}

In summary, we report the syntheses and characterization of a new series of NIR Ir(III) complexes (1-5). These complexes exhibit moderate NIR phosphorescence with peak wavelengths around 910-920 nm at RT. As supported by the TDDFT approach, the transition mainly involves benzoisoquinoline ${ }^{3} \pi-\pi^{*}$ intraligand charge transfer and metal (Ir) to benzoisoquinoline charge transfer. The relatively weak NIR emission can be tentatively rationalized by the low energy gap of which the radiationless deactivation may be governed by the large amplitude vibration and, in part, the phenyl torsional motions at the benzoquinoxaline sites. Knowing that current interest in $\operatorname{Ir}(\mathrm{III})$ types of phosphorescence emitter is focused on the $\operatorname{Ir}($ III)-type OLED, to switch gears in research orientation, future applications of the titled NIR complexes and (or) relevant derivatives may be motivated by the strategy of using these complexes in the fabrication of photovoltaic devices (23). Focus on this approach is in progress.

\section{Acknowledgment}

We thank the National Science Council of Taiwan, Republic of China, for financial support (grant Nos. NSC 91-2119M-002-016) and (NSC 91-2113-M-007-006). 


\section{References}

1 (a) B. O'Regan and M. Graetzel. Nature (London), 353, 737 (1991); (b) A. Hagfeldt and M. Gratzel. Acc. Chem. Res. 33, 269 (2000); (c) D. Kuciauskas, M.S. Freund, H.B. Gray, J.R. Winkler, and N.S. Lewis. J. Phys. Chem. B, 105, 392 (2001); (d) M. Gratzel. Nature (London), 414, 338 (2001).

2. (a) R.J. Mears and S.R. Baker. Opt. Quantum Electron. 24, 517 (1992); (b) E. Desurvire. Phys. Today, 97, 20 (1994); (c) N. Ono, S. Ito, C.H. Wu, C.H. Chen, and T.C. Wen. Chem. Phys. 262, 467 (2000).

3. (a) M.A. Baldo, D.F. O'Brien, Y. You, A. Shoustikov, S. Sibley, M.E. Thompson, and S.R. Forrest. Nature (London), 395, 151 (1998); (b) Y.-L. Tung, S.-W. Lee, Y. Chi, Y.-T. Tao, C.-H. Chien, Y.-M. Cheng, P.-T. Chou, S.-M. Peng, and C.-S. Liu. J. Mater. Chem. 15, 460 (2005); (c) A. Tsuboyama, H. Iwawaki, M. Furugori, T. Mukaide, J. Kamatani, S. Igawa, T. Moriyama, S. Miura, T. Takiguchi, S. Okada, M. Hoshino, and K. Ueno. J. Am. Chem. Soc. 125, 12971 (2003); (d) Y.-L. Tung, S.-W. Lee, Y. Chi, L.-S. Chen, C.-F. Shu, F.-I. Wu, A.J. Carty, P.-T. Chou, S.-M. Peng, and G.-H. Lee. Adv. Mater. 17, 1059 (2005).

4. (a) E.M. Kober, J.V. Caspar, R.S. Lumpkin, and T.J. Meyer. J. Phys. Chem. 90, 3722 (1986); (b) L. Della Ciana, W.J. Dressick, D. Sandrini, M. Maestri, and M. Ciano. Inorg. Chem. 29, 2792 (1990).

5. (a) T.J. Foley, B.S. Harrison, A.S. Knefely, K.A. Abboud, J.R. Reynolds, K.S. Schanze, and J.M. Boncella. Inorg. Chem. 42, 5023 (2003); (b) W.-K. Wong, A. Hou, J. Guo, H. He, L. Zhang, W.-Y. Wong, K.-F. Li, K.-W. Cheah, F. Xue, and T.C.W. Mak. J. Chem. Soc. Dalton Trans. 3092 (2001); (c) A. Vogler and H. Kunkely. Top. Curr. Chem. 213, 143 (2001); (d) N.M. Shavaleev, L.P. Moorcraft, S.J.A. Pope, Z.R. Bell, S. Faulkner, and M.D. Ward. Chem. Eur. J. 9, 5283 (2003); (e) A.M. Klonkowski, S. Lis, M. Pietraszkiewicz, Z. Hnatejko, K. Czarnobaj, and M. Elbanowski. Chem. Mater. 15, 656 (2003).

6. (a) I.B. Rietveld, E. Kim, and S.A. Vinogradov. Tetrahedron, 59, 3821 (2003); (b) V.V. Rozhkov, M. Khajehpour, and S.A. Vinogradov. Inorg. Chem. 42, 4253 (2003).

7. (a) A. Juris, V. Balzani, S. Campagna, G. Denti, S. Serroni, G. Frei, and H.U. Guedel. Inorg. Chem. 33, 1491 (1994); (b) A. Mamo, A. Juris, G. Calogero, and S. Campagna. Chem. Commun. (Cambridge), 1225 (1996); (c) M.K. Nazeeruddin, R. Humphry-Baker, M. Gratzel, and B.A. Murrer. Chem. Commun. (Cambridge), 719 (1998).

8. (a) W.R. Thiel and J. Eppinger. Chem. Eur. J. 3, 696 (1997); (b) S.P. Singh, D. Kumar, B.G. Jones, and M.D. Threadgill. J. Fluorine Chem. 94, 199 (1999).

9. M. Nonoyama. J. Organomet. Chem. 86, 263 (1975).

10. R.C. Benson and H.A. Jues. J. Chem. Eng. Data, 22, 379 (1977).

11. C. Lee, W. Yang, and R.G. Parr. Phys. Rev. B, 37, 785 (1988).

12. A.D. Becke. J. Chem. Phys. 98, 5648 (1993).
13. (a) P.J. Hay and W.R. Wadt. J. Chem. Phys. 82, 270 (1985); (b) W.R. Wadt and P.J. Hay. J. Chem. Phys. 82, 284 (1985); (c) P.J. Hay and W.R. Wadt. J. Chem. Phys. 82, 299 (1985).

14. P.C. Hariharan and J.A. Pople. Mol. Phys. 27, 209 (1974).

15. (a) C. Jamorski, M.E. Casida, and D.R. Salahub. J. Chem. Phys. 104, 5134 (1996); (b) M. Petersilka, U.J. Grossmann, and E.K.U. Gross. Phys. Rev. Lett. 76, 1212 (1996); (c) R. Bauernschmitt, R. Ahlrichs, F.H. Hennrich, and M.M. Kappes. J. Am. Chem. Soc. 120, 5052 (1998); (d) M.E. Casida. J. Chem. Phys. 108, 4439 (1998); (e) R.E. Stratmann, G.E. Scuseria, and M.J. Frisch. J. Chem. Phys. 109, 8218 (1998).

16. M.J. Frisch, G.W. Trucks, H.B. Schlegel, G.E. Scuseria, M.A. Robb, J.R. Cheeseman, J.A. Montgomery, Jr., T. Vreven, K.N. Kudin, J.C. Burant, J.M. Millam, S.S. Iyengar, J. Tomasi, V. Barone, B. Mennucci, M. Cossi, G. Scalmani, N. Rega, G.A. Petersson, H. Nakatsuji, M. Hada, M. Ehara, K. Toyota, R. Fukuda, J. Hasegawa, M. Ishida, T. Nakajima, Y. Honda, O. Kitao, H. Nakai, M. Klene, X. Li, J.E. Knox, H.P. Hratchian, J.B. Cross, V. Bakken, C. Adamo, J. Jaramillo, R. Gomperts, R.E. Stratmann, O. Yazyev, A.J. Austin, R. Cammi, C. Pomelli, J.W. Ochterski, P.Y. Ayala, K. Morokuma, G.A. Voth, P. Salvador, J.J. Dannenberg, V.G. Zakrzewski, S. Dapprich, A.D. Daniels, M.C. Strain, O. Farkas, D.K. Malick, A.D. Rabuck, K. Raghavachari, J.B. Foresman, J.V. Ortiz, Q. Cui, A.G. Baboul, S. Clifford, J. Cioslowski, B.B. Stefanov, M.A.G. Liu, A. Liashenko, P. Piskorz, I. Komaromi, R.L. Martin, D.J. Fox, T. Keith, Al-Laham, C.Y. Peng, A. Nanayakkara, M. Challacombe, P.M.W. Gill, B. Johnson, W. Chen, M.W. Wong, C. Gonzalez, and J.A. Pople. Gaussian 03. Revision C.02 [computer program]. Gaussian, Inc., Wallingford, Conn. 2004.

17. G.B. Caygill, R.M. Hartshorn, and P.J. Steel. J. Organomet. Chem. 382, 455 (1990).

18. F.O. Graces, K.A. King, and R.J. Watts. Inorg. Chem. 27, 3464 (1988).

19. S. Lamansky, P. Djurovich, D. Murphy, F. Abdel-Razzaq, H.-E. Lee, C. Adachi, P.E. Burrows, S.R. Forrest, and M.E. Thompson. J. Am. Chem. Soc. 123, 4304 (2001).

20. (a) Y. Ohsawa, S. Sprouse, K.A. King, M.K. DeArmond, K.W. Hanck, and R.J. Watts. J. Phys. Chem. 91, 1047 (1987); (b) P.J. Hay. J. Phys. Chem. A, 106, 1634 (2002); (c) F.-M. Hwang, H.-Y. Chen, P.-S. Chen, C.-S. Liu, Y. Chi, C.-F. Shu, F.-I. Wu, P.-T. Chou, S.-M. Peng, and G.-H. Lee. Inorg. Chem. 44, 1344 (2005).

21. D.L. Dexter. J. Chem. Phys. 21, 836 (1953).

22. For example, see: P.T. Chou, Y.C. Chen, C.Y. Wei, S.J. Chen, H.L. Lu, and T.H. Wei. J. Phys. Chem. A, 101, 8581 (1997), and refs. therein.

23. (a) P.A. Anderson, F.R. Keene, T.J. Meyer, J.A. Moss, G.F. Strouse, and J.A. Treadway. J. Chem. Soc. Dalton Trans. 3820 (2002); (b) M.K. Nazeeruddin, S.M. Zakeeruddin, J.-J. Lagref, P. Liska, P. Comte, C. Barolo, G. Viscardi, K. Schenk, and M. Graetzel. Coord. Chem. Rev. 248, 1317 (2004). 
Copyright of Canadian Journal of Chemistry is the property of NRC Research Press and its content may not be copied or emailed to multiple sites or posted to a listserv without the copyright holder's express written permission. However, users may print, download, or email articles for individual use. 